UDC 378.091.12:159-051

DOI: $10.52534 / \mathrm{msu}-$ pp.7(3).2021.71-77

Tetiana D. Shcherban ${ }^{\star}$, Iryna I. Bretsko, Victoriya S. Varha

Mukachevo State University

89600, 26 Uzhhorodska Str., Mukachevo, Ukraine

\title{
Psychological and Pedagogical Features of Training Future Psychologists
}

\author{
Article's History: \\ Received: 19.03.2021 \\ Revised: 15.05.2021 \\ Accepted: 22.07.2021
}

\section{Suggested Citation:}

Shcherban, T.D., Bretsko, I.I., \& Varha, V.S. (2021). Psychological and pedagogical features of training future psychologists. Scientific Bulletin of Mukachevo State University. Series "Pedagogy and Psychology", 7(3), 71-77.

\begin{abstract}
The relevance of the topic submitted for consideration in the framework of this scientific research is determined by the need for a deep study of various aspects of training future specialists in the field of psychology in higher pedagogical educational institutions, in the context of the wide demand for the specialty of a psychologist in society and the need to improve the quality of training specialists in this field. The main purpose of this research work is to study the key features of psychological and pedagogical training of future psychology specialists at the stage of training in an educational institution, from the point of view of forming their competencies necessary for conducting further professional activities. The leading approach in this research work is a combination of methods of systematic analysis of the currently available methods of training specialists in the field of psychology with an analytical study of the features of teaching in modern educational institutions, from a pedagogical and psychological point of view, in order to form the most complete and objective picture of scientific research. The results obtained in the course of this research reflect the existing problems of the modern education system in the context of the training system of future psychologists, both professional and from a purely pedagogical point of view, and serve as a qualitative basis for formulating final conclusions based on them. The results and conclusions of this research work are of significant practical importance for improving the training systems of future psychologists in modern educational institutions in terms of forming their competencies necessary for high-quality further professional activity
\end{abstract}

Keywords: pedagogy and psychology, training of psychologists, features of training of psychologists, professional self-determination

\section{INTRODUCTION}

In recent years, the dynamics of the development of modern society determines the choice of social development tasks related to decision-making by representatives of the younger generation regarding their own professional orientation. In this context, the profession of a psychologist is gaining popularity, which is applicable in all spheres of life of modern society. This profession is also in demand in the activities of various structures and public organizations [1]. All this determines the importance of building a high-quality level of training of modern psychologists that corresponds to the realities and tasks that representatives of this profession face during their professional activity.

Even at the stage of training in the higher education system, future specialists in the field of psychology are faced with the need to form special competencies, both pedagogical and highly specialized, necessary for high-quality further performance of their professional duties [2]. The main features of training future specialists in the psychological field at the stage of training in the higher education system today are determined both by the social needs for the services of specialists in this field, and by the realities of the current system of training specialists in this field as a whole. The system of training future psychologists within the realities of modern higher education largely leaves much to be desired due to a large number of issues, such as: issues of financing higher educational institutions, as a result of which leading specialists in the field of psychology from among the teaching staff are forced to start a private practice and stop teaching, the weakness of the scientific and methodological base in some cases, and so on.

It is worth noting that today the problem of personal readiness of future psychologists for university training, as well as their further self-realization, is very acute, already taking into account the passage of a training program with 
an emphasis on the development of pedagogical skills (if we are talking about teachers-psychologists), as well as personal psychological resistance to the implementation of their direct professional activities. At the same time, the problem of professional self-determination of future psychologists also lies in the fact that in recent years, among young people studying at universities, there is a clear tendency to complicate the socio-psychological personal characteristics of students within a specific direction of university training [3]. In particular, this is reflected in the emergence of so-called "risk groups" among young students, with a low level of socialization and significant interpersonal problems. This state of affairs is largely due to the primitive interests of students, lack of skills in independent analysis and practical decision-making, as well as general psychological immaturity. Often, such problems remain unresolved for a significant period of time, complicating the already difficult work of specialists in the field of psychology already at the stage of professional activity after graduation.

Psychological and pedagogical features of training future psychologists at the stage of higher education consist of the formation of such a learning environment that could contribute to the highest quality disclosure of individual features of students, to arouse their interest in learning, obtaining new knowledge and actively implementing it in professional activities in the future [4]. At the same time, the peculiarities of the professional activity of a psychologist require special psychological stability and the ability to find the right recommendations in each specific case, which can be practically achieved only with the help of long-term individual practical classes, taking into account the individual characteristics of each student.

\section{MATERIALS AND METHODS}

Psychological and highly specialized training of future psychologists is an inseparable process, the final quality of which is largely determined both by the personal qualities of students and university teachers, and by the desire of students themselves to be realized in the future profession, gain new knowledge and successfully apply it in practice [5]. Relationship psychology is inherently dynamic and the timely and high-quality implementation of the principles of development of future specialists in the field of psychology, even at the stage of studying at the university, depends on the quality of their professional activities and the level of solving practical problems of providing psychological assistance.

This scientific study used a combination of methods of systematic analysis of the currently available methods of training specialists in the field of psychology with an analytical study of the features of teaching in modern educational institutions, which were considered from a pedagogical and psychological point of view. The chosen combination of methods provides for the implementation of a systematic study of the methods of training psychologists developed and implemented in the program of educational institutions, in combination with the analysis of the features of the implementation of the curriculum for teaching psychology in educational institutions, as well as the consistent formation of future psychologists of pedagogical and highly specialized knowledge which is necessary for high-quality professional activities within the chosen speciality. In addition, a qualitative assessment of the features of both pedagogical and psychological training of future teachers-psychologists who plan to carry out professional activities in the modern education system is formed.

The theoretical basis of this educational and research work was numerous theoretical studies of Ukrainian and mainly foreign authors who studied the issues of psychological and pedagogical training of future psychologists to conduct professional activities, the development of their necessary competencies, both pedagogical and psychological properties necessary for the qualitative performance of their professional duties in the future.

In order to ensure objective and complete disclosure of the stated topic of scientific research, as well as to facilitate the perception of the submitted material, all information taken from the works of foreign authors and submitted in the order of citation in this scientific study has been translated into Ukrainian.

This research was carried out in several stages.

1. At the first stage of this research work, a systematic study of the current methods of training specialists in the field of psychology was carried out, with the identification of their main patterns that are important from the point of view of forming future specialists in the field of psychology necessary for conducting their professional activities competencies, both pedagogical and highly specialized properties.

2. At the second stage of this research work, an analytical study of the features of teaching in modern educational institutions, from a pedagogical and psychological point of view, was carried out as a method for determining the features of the formation of professional competencies of future psychologists. At the same time, at this stage of scientific research, a comparative analysis of the results obtained with the results and conclusions obtained by foreign researchers on the issues included in the topic of this scientific work was carried out, which made it possible to compare the methods used in this scientific study with the final results and compare them with the methods and results obtained by other researchers submitted for consideration.

3. At the concluding stage of this scientific study, its final conclusions were formed, based on the results obtained. In general, the results and conclusions of this scientific work actually complete the entire complex of scientific research aimed at determining the main psychological and pedagogical features of training future specialists in the field of psychology to conduct professional activities. In addition, the conclusions are a practical reflection of the main results of this scientific work.

\section{RESULTS AND DISCUSSION}

The conscious choice of profession by future psychologists does not occur immediately upon admission to an educational institution, but only some time after completing 
training. At the same time, to make a final decision on the choice of this profession, it is necessary to meet a number of conditions that determine both the selection criteria and the general direction of further professional activity.

Numerous scientific studies show that in recent years there has been a certain gap between the training of future psychologists in higher education institutions and real practical requirements for their competence and the actual level of training. This explains the small number of university graduates of psychological specialities who got a job in their speciality after training. At the same time, graduates ' dissatisfaction with their profession is growing, and novice psychologists themselves do not fully meet the requirements of modern employers. The reasons for this situation also lie in the low level of professional and pedagogical competence of future psychologists even at the stage of mastering the chosen profession in an educational institution.

In this context, an important factor should be considered the correct setting of priorities for highly specialized and pedagogical training of future specialists in the psychological field even at the stage of their training in an educational institution. It is worth highlighting several main features in the development of highly specialized competencies of future psychologists at this stage, taking into account their personal characteristics:

- ability to implement a creative approach in professional activities related to the ability to find non-standard solutions to typical professional situations;

- ability to self-educate, search for new learning opportunities and improve professional skills and competencies;

- ability to managerial reflection, based on the principles of self-discovery and self-realization in professional activities.

The development of psychological competence related to the ability to make non-standard decisions in situations related to the professional activities of psychologists involves conducting special training sessions, both in groups and individually. The main task of training aimed in this way is the consistent formation of students who have chosen the profession of a psychologist, the ability to find new solutions to typical situations that will constantly occur in their professional activities. It is worth noting that this competence will be essential not only in the process of implementing tasks related to the professional activity of a psychologist, but also in everyday situations of the future psychologist's life.

Self-education is a mandatory element of the professional activity of a future psychologist. That is why even at the stage of training in an educational institution, during the training of psychologists, a mandatory emphasis is placed on developing the ability to find the necessary information and correctly apply it in everyday practice, both professional and personal. In addition, the development of needs for professional self-development of the psychologist's personality should also be carried out taking into account the individual and personal characteristics of students, according to which the stages of university training in this direction are built.
Any psychologist acts to a certain extent as a manager of his client's emotions, so the reflexive-managerial approach in training future psychologists is extremely important from the point of view of forming their appropriate professional competencies. The desire for self-discovery and self-organization of the future psychologist play a significant role in this context, since knowledge and understanding of their own reflections, the ability to keep them under control and direct them in the right direction during the performance of their professional duties are mandatory competencies of a competent specialist in the field of practical psychology.

Psychological training of future psychology specialists at the stage of training in an educational institution must necessarily include exercises to develop the ability to withstand stressful loads for a long time [6]. Current changes in the modern education system dictate the need to find and implement new opportunities to improve the professional skills of future psychologists at the stage of their preparation for active work. In this context, individual classes with students of psychological specialties of higher education institutions are of particular importance, conducted taking into account their personal qualities and aimed at developing their competencies necessary in the future for successful psychological practice.

In particular, as such classes can be distinguished game training sessions, the task of which is to modell various situations that arise in the real practice of a psychologist directly in working with clients. Situations may involve modelling conflicts or certain elements of everyday professional communication, during which participants in simulation games consistently express empathy or rejection of certain situations that may take place in reality. It is necessary to identify the following main aspects that you should pay attention to in the process of performing game simulation of situations that are as close as possible to the real practice of psychologists:

- speed of the student's response to a change in the game situation, which leads to its complication;

- ability to find arguments that can direct the conversation in the right direction for the implementation of psychological reception tasks;

- the ability to remain calm in any, even the most difficult situations that arise during the reproduction of the simulation game.

A characteristic feature of such classes, which contribute to the formation of a high level of psychological stability of future psychologists and their professional competencies, is high dynamism, because it is in the conditions of artificially created need for rapid decision-making that contribute to redirecting the client's attention to individual, nodal elements of communication during a psychological reception, psychological stability and the ability to constantly retain the client's attention are formed [7].

Modern methods of training psychologists within the framework of training programs of higher and secondary specialized educational institutions do not fully meet the 
requirements of today, for this reason, the use of non-traditional methods for developing professional skills of future psychologists is better in terms of improving the quality of professional training and more accurately meeting the requirements of the modern market for providing psychological assistance. Non-traditional training methods developed using simulation games that are as close as possible to the realities of the present time are the most effective in terms of obtaining real psychological skills of conducting reception of clients and work with client requests. It is logical to conclude that the effectiveness of practical activities of graduates of psychology departments of modern higher educational institutions is largely determined by the level of development of their socio-cultural competence, which is expressed in the ability to process client requests and quickly respond to changes in the client's mood and situation during session. In addition, pedagogical skills, expressed in the ability to persuade the visitor to their point of view and conduct a dialogue in the right direction, are of great importance [8].

The main stages of psychological and pedagogical training of future psychologists in the process of mastering the profession in an educational institution are:

1) theoretical acquaintance with the basics of the profession, the study of the basic elements of further activities of a practicing psychologist;

2) conducting practical training sessions that are as close as possible to the conditions of real reception of clients;

3 ) practice with real clients under the guidance of an experienced teacher with considerable practical experience in psychological counseling [8].

At the stage of studying the basics of the profession of a psychologist, the student must improve the level of their own social competence, which is expressed in high sociability, the ability to listen and hear the client, knowledge and ability to apply basic techniques of psychological influence, etc. [9]. Features of training future psychologists in terms of developing their psychological stability and high professional competencies also consist in the ability of teachers of future specialists to find the right approach to each student, which in the future will contribute to the qualitative development of all the above competencies and successful conduct of professional activities in the future.

Intensive socio-economic changes taking place in modern society determine the needs for mobility and competitiveness of the individual. Students of psychological specialties of higher education institutions who complete their studies and enter professional activities are required to have a high level of psychological literacy and the ability to meet the requirements of the time, both in personal and professional relationships.

Assessment of the current trends in the system of training future teachers-psychologists makes it possible to conclude that it is necessary to improve the quality of training of specialists in the field of psychology, both from a purely pedagogical point of view and in terms of developing their professional skills that are important in further practical activities. The analysis of teaching quality and the training level of graduates of psychological specialities reveals the presence of numerous training problems related to both scientific and methodological equipment and connected to the peculiarities of the labor market, where there is a tendency of non-compliance of employers' requirements with the real level of professional competence of graduates of modern higher education institutions [10].

Today, the problems of professional orientation of future psychologists are extremely acute in the system of educational institutions that offer applicants the opportunity to receive psychological education. Qualitative orientation of specialists in the psychological field is impossible without the full development of a set of competencies necessary for the effective performance of their professional duties in the future. In this context, the teaching staff of a modern educational institution is required to develop and implement effective methods for developing professional competencies, proven by real practical experience. The problem is all the more significant because, as social monitoring data show, most graduates of psychology departments of modern educational institutions do not have a clear idea of their own professional future. They have rather unclear professional orientations, in addition, directly in the course of training, they receive rather vague skills that do not meet the current requirements of employers. That is why such specialists become uncompetitive in modern conditions. For this reason, it is necessary to recognize as justified the common requirements for having at least three years of work experience as a psychologist after graduation, voiced by employers during admission for the relevant position. In conditions of limited opportunities for professional and career development, many graduates of psychology departments of modern educational institutions do not start independent professional activity, remaining at the level of competencies acquired at the time of graduation [11].

The problem of professional self-determination of future psychologists is closely intertwined with the problems of their quality training, both pedagogical and highly specialized. Teachers-psychologists, who are in demand in the system of modern secondary schools, undergo professional training at the stage of training in a pedagogical university, where they receive the basics of pedagogical literacy and develop the ability to assess the situation in the school, pedagogical environment, taking into account its difficulties and characteristic features. In this context, the issues of training future specialists, combining the competencies of a teacher and a psychologist, require detailed consideration already at the stage of forming a university training program, taking into account the realities of their further professional activity [12].

In the process of considering the specifics of professional training of future psychologists, it is necessary to take into account not only socio-psychological, but also personal aspects. Taking into account all the stages of formation and professional self-determination of future specialists, as well as all possible connections with the personal 
sphere, it is worth noting the possibilities for building psychologically justified and appropriate from the point of view of pedagogy tactics for training future psychologists and strategies for conducting classes within the training program aimed at developing students' professional competencies necessary for further professional activity in the psychological sphere [13]. It is clear that the main aspect in the process of forming high standards of pedagogical and professional training should be to accept the real needs for the competence of future specialists, their ability to solve specific tasks and steadily improve the overall level of their own psychological literacy.

In the conditions of the modern education system, the training of future psychologists is often aimed at developing their practical skills of effective interaction with the environment, which can also be expressed in the ability to get the necessary information at the right time and apply it usefully to solve specific situations that take place in their professional activities. The competencies of a teacher and psychologist identified in modern standards of the education system are not always sufficient in practice, and therefore sometimes require rethinking and modifying the system of training future specialists in this field and developing these skills.

The modern educational psychologist is a creative individual, capable of independently rethinking the various features of training at the stage of higher education in terms of realities of the present and independently make the necessary adjustments to the current situation. However, such an ability to make independent decisions and actions in a certain direction should be nurtured throughout the entire period of study within the chosen speciality. This suggests a conclusion about the need to develop special psychological and pedagogical training programs within the educational system, aimed primarily at educating students' capability for critical thinking and independent analysis of the current situation, with the ability to find optimal solutions to existing problems and effectively apply them in practice.

Today, one of the priority areas of training teacherspsychologists is the consistent improvement of their professional competencies to such a level that could allow them in the conditions of independent professional activity to make timely and independent decisions on the implementation of specific measures for the development of children and adolescents, with mandatory consideration of their age characteristics, individual characteristics, which, in general, will provide teachers with significant assistance in the development and practical use of measures for comprehensive improvement of educational work in the conditions of the teaching staff [14].

At the same time, among the main issues of graduates of higher and secondary educational institutions that solve the issues of training psychologists, there are:

- low level of professional and personal training;

- low level of theoretical and practical knowledge and skills;

- inability at the beginning of their professional activity to effectively apply the obtained theoretical developments in practice.

Low self-esteem of graduates, isolation of their knowledge from the realities of the surrounding life, lack of understanding of the rules of existence in the modern labour collective often leads to the fact that graduates of psychological and pedagogical specialities of modern universities are disappointed in the profession, not being objectively ready to perform their professional duties efficiently [12]. The greater becomes the importance of the correct construction of the training system for future psychologists at the stage of higher education, the qualitative development of their pedagogical and psychological competencies.

The level of academic and professional competence of graduates of psychological specialties of modern higher and secondary educational institutions should be correlated with general competencies related to the specific environments in which the graduate of the educational institution enters after receiving a diploma. Moreover, it is the so-called general competencies that determine ability to self-study, communication within a particular society, mobility in a changing environment. With regard to the analysis of the competencies of teachers-psychologists, it is worth noting that the qualification characteristics of employees of the modern education system also determine the general competencies of former students and subject-related competencies directly related to a certain subject included in the training program in the educational institution where the psychologist conducts their professional activity [15]. As for highly specialized competencies, these include certain skills acquired in the process of obtaining higher education during specific industrial or pre-graduate internships. These also include counselling practices, correctional and diagnostic practices, as well as practical activities of a purely pedagogical orientation related to establishing and maintaining close contact with children and their parents.

The psychodiagnostic competence of the future teacher-psychologist deserves a separate detailed consideration. Knowledge of specific research methods in certain issues is mandatory in order to avoid unprofessional judgments about certain issues that are studied within the framework of the professional activity of a teacher-psychologist in the future [16]. Psychodiagnostic competence is associated with the use of special tests that correspond to the specific level of qualification of the teacher-psychologist who uses them. It is clear that the skills of using such tests are "instilled" at the stage of training in a pedagogical university as a part of the process of obtaining a psychologist's speciality. In addition, if the proposed testing methodology provides for a higher level of qualification, it can be replaced with a simpler and more understandable one in order to facilitate the perception of the information provided. Such techniques should be demonstrated to students at the stage of training in the speciality of a psychologist in an educational institution. Issues of psychological counselling are solved in a similar way. Obtaining specific results in this context depends on the level of training of the specialist 
received at the training stage, as well as on personal skills and abilities in the practical application of these methods of work [17].

Training of future psychologists should include explaining the essence of various theoretical approaches currently used in consulting practice. A specialist with a high level of professional competence uses the principles of eclecticism in their practical activities, which distinguishes them favourably as a professional capable of timely implementation of effective consulting techniques under non-standard conditions to achieve optimal results. The level of competence of a modern psychologist is determined precisely by the amount of practical knowledge and the ability to apply it in daily activities.

Training of a psychologist involves the formation of a complete system of knowledge and skills within the limits of professional competencies, which will subsequently provide them with a high level of not only professional suitability, but also demand as a specialist of a certain orientation. It also provides for the preparation of a psychological plan that takes into account the high level of development of skills to manage one's own psychological state in any situation. Such competence is of great importance from the point of view of the level of psychological stability of the specialist and the ability to abstract directly from what happens during the reception or provision of consulting services, which positively affects the overall quality of services provided by the specialist [18].

The psychological competence of a modern graduate of a psychological speciality of an educational institution, regardless of the level of accreditation, is also determined by the graduate's general professional competence and the ability to effectively solve the most difficult situations that may occur in practice. The psychological competence of a psychologist presupposes a multilevel personality formation, which is based on the main motives of professional choice, the total set of knowledge and skills acquired at the stage of training the profession and consistently mastered in further activities [19]. Among the main factors that determine the psychological competence of a specialist in the field of pedagogy and psychology, it is worth highlighting:

- the ability to correctly diagnose and apply the material obtained in the diagnostic process in determining the direction of personal development;

- ability to provide high-quality psychological assistance to all individuals in difficult periods of their life;

- ability to correctly apply pedagogical communication skills;

- the desire to develop steadily from a professional point of view.

Special features of training psychologists at the stage of training in the profession involve the development of these and other competencies, which should subsequently ensure a high level of services provided by them and correspond to the level of their professional skills to the realities of today.

\section{CONCLUSIONS}

A scientific study of the features of psychological and pedagogical training of future psychologists in the modern education system has led to such conclusions. The work of a modern psychologist is associated with constant stress, so training for a high level of stress resistance should be considered the most important area of training for future specialists in the psychological field in the system of modern higher education. This result can be achieved by conducting special training exercises, both collective and individual, aimed at developing the future psychologist's appropriate level of culture of communication with clients and rapid response to changing customer requests. Such training sessions are a special simulation of situations that are as close as possible to the conditions of real session, which should be managed by a teacher who has real experience in psychological practice.

At the moment, there are significant differences between the level of employers' requirements for the qualifications, professional skills and competence of psychologists and the real competencies that graduates of psychology departments of modern educational institutions have after completing their studies. This situation can be corrected by applying non-traditional methods in the system of university training of future psychologists based solely on real, practical experience of psychological activity, which, at the same time, does not contradict the requirements of the student training program in a particular educational institution. At the same time, a mandatory element of training future graduates, both in pedagogical and highly specialized terms, should be considered conducting practical classes that involve their direct participation in working with client requests, independently and also under the guidance of an experienced mentor. This will contribute to honing psychological skills and developing the competencies needed in the future for fully independent practical activities. In addition, at the first stages, monitoring the future psychologist's performance of their professional duties will help to identify existing mistakes and eliminate them in a timely, quality manner.

The study of the peculiarities of training future psychologists at the stage of professional training makes it possible to identify the main inconsistencies of training programs in modern realities in a timely manner and find ways to resolve the situation. Improving the training of future psychologists from both pedagogical, professional and psychological points of view, in the future will promote the education of high-quality staff who can effectively solve any task in the field of psychological care in any situation.

\section{REFERENCES}

[1] Bensadon, B. (2016). Psychology and geriatrics (1st ed.). London: Academic Press.

[2] Bradley, S., \& Green, C. (2020). The economics of education (2nd ed.). London: Academic Press.

[3] Huang, X., \& Wang, C. (2021). Factors affecting teachers' informal workplace learning: The effects of school climate and psychological capital. Teaching and Teacher Education, 103, article number 103363. 
[4] Liu, P.P., Savitz-Romer, M., Perella, J., Hill, N.E., \& Liang, B. (2018). Student representations of dyadic and global teacher-student relationships: Perceived caring, negativity, affinity, and differences across gender and race/ethnicity. Contemporary Educational Psychology, 54, 281-296.

[5] Chaharbashloo, H., Gholami, K., Aliasgari, M., Talebzadeh, H., \& Mousapour, N. (2020). Analytical reflection on teachers' practical knowledge: A case study of exemplary teachers in an educational reform context. Teaching and Teacher Education, 87, article number 102931.

[6] Newton, K.J., Sperling, R.A., \& Martin, A.J. (2017). Learning disabilities, attention-deficit hyperactivity disorder, and executive functioning: Contributions from educational psychology in progressing theory, measurement, and practice. Contemporary Educational Psychology, 50, 1-3.

[7] Dent, J., Harden, R., \& Hunt, D. (2021). A practical guide for medical teachers (5th ed.). Oxford: Elsevier.

[8] Wigfield, A., \& Koenka, A.C. (2020). Where do we go from here in academic motivation theory and research? Some reflections and recommendations for future work. Contemporary Educational Psychology, 61, article number 101872.

[9] Zavrazhnov, V.V., \& Shchelina, T.T. (2010). Professional self-determination of future pedagogues-psychologists: Psychological and pedagogical aspect. World of Science, Culture, Education, 2(21), 175-177.

[10] Zhazhaeva, D.D., \& Khapacheva, S.M. (2018). Modern approaches to training future educational psychologists to work in the system of inclusive education. Problems of Modern Pedagogical Education, 60(2), 146-150.

[11] Schultz, P. (2020). Race focusing and reimaging research: Where do we go from here? Contemporary Educational Psychology, 61(4), article number 101871.

[12] Nolen, S.B. (2020). A situative turn in the conversation on motivation theories. Contemporary Educational Psychology, 61, article number 101866.

[13] Van Valkengoed, A.M., Steg, L., Perlaviciute, G., Schultz, P.W., Brosch, T., Gatersleben, B., Nordlund, A., Pahl, S., \& Whitmarsh, L. (2021). Theory enhances impact. Reply to: “The case for impact-focused environmental psychology". Journal of Environmental Psychology, 75(3), article number 101597.

[14] Ryan, R.M., \& Deci, E.L. (2020). Intrinsic and extrinsic motivation from a self-determination theory perspective: Definitions, theory, practices, and future directions. Contemporary Educational Psychology, 61, article number 101860.

[15] Urban, T., \& Kaplan, A. (2020). The origins, evolution, and future directions of achievement goal theory. Contemporary Educational Psychology, 61, article number 101862.

[16] McCrudden, M.T., Marchand, G., \& Schultz, P. (2019). Mixed methods in educational psychology inquiry. Contemporary Educational Psychology, 57, 1-8.

[17] Kaufmann, E. (2020). How accurately do teachers' judge students? Re-analysis of Hoge and Coladarci (1989) meta-analysis. Contemporary Educational Psychology, 63, article number 101902.

[18] Richard, D., \& Huprich, S. (2008). Clinical psychology (1st ed.). London: Academic Press.

[19] Tam, K.P., \& Milfont, T.L. (2020). Towards cross-cultural environmental psychology: A state-of-the-art review and recommendations. Journal of Environmental Psychology, 71, article number 101474.

\section{Тетяна Дмитрівна Щербан, Ірина Іванівна Брецко, Вікторія Степанівна Варга}

Мукачівський державний університет

89600, вул. Ужгородська, 26, м. Мукачево, Україна

\section{Психолого-педагогічні особливості підготовки майбутніх психологів}

Анотація. Актуальність тематики, винесеної на розгляд у межах цього наукового дослідження, визначається необхідністю глибокого вивчення різних аспектів підготовки майбутніх фахівців сфери психології у вищих педагогічних навчальних закладах, в контексті широкої затребуваності спеціальності психолога в суспільстві і необхідності вдосконалення якості підготовки фахівців цього напряму. Основною метою цієї науково-дослідної роботи є вивчення ключових особливостей психологічної та педагогічної підготовки майбутніх фахівців психології на етапі навчання в навчальному закладі, з точки зору формування у них компетенцій, необхідних для ведення подальшої професійної діяльності. Провідним підходом у цій науково-дослідній роботі вибрано поєднання методів системного аналізу наявних на сьогодні методик підготовки фахівців у галузі психології 3 аналітичним дослідженням особливостей викладання в сучасних навчальних закладах, 3 педагогічної та психологічної точок зору, з метою формування найбільш повної та об’єктивної картини наукового дослідження. Отримані в процесі цього наукового дослідження результати відображають наявні проблеми сучасної системи освіти в контексті особливостей системи підготовки майбутніх психологів, як професійного характеру, так і з виключно педагогічної точки зору, а також виступають якісною основою для формулювання підсумкових висновків на їхній основі. Результати та висновки цієї науково-дослідної роботи мають істотне практичне значення для удосконалення систем підготовки майбутніх психологів у сучасних навчальних закладах 3 точки зору формування у них компетенцій, необхідних для якісного надалі ведення професійної діяльності

Ключові слова: педагогіка і психологія, підготовка психологів, особливості навчання психологів, професійне самовизначення 